\title{
Corticotropin-releasing Hormone Is Produced by Rat Corticotropes and Modulates ACTH Secretion in a Paracrine/Autocrine Fashion
}

\author{
Francesca Pecori Giraldi and Francesco Cavagnini \\ Ospedale San Luca, IRCCS, Istituto Auxologico Italiano, 2nd Chair of Endocrinology, University of Milan, Milan, 20149 Italy
}

\begin{abstract}
Anterior pituitary hormone secretion is mainly regulated by hypothalamic releasing factors, which reach the pituitary via portal vessels. It has been demonstrated recently that these peptides can also be produced by the pituitary itself, thus possibly modulating hormone secretion in a paracrine/ autocrine fashion. The object of this study was to seek evidence for the synthesis and secretion of corticotropin-releasing hormone (CRH) within the anterior pituitary and to ascertain its biological relevance. Messenger RNA from adult rat anterior pituitary fragments and cell cultures was reverse transcribed and subjected to PCR amplification using primers specific to the rat $\mathrm{CRH}$ gene. As in the hypothalamus, a single 232-bp band was obtained. The correspondence of the amplified fragment to the sequence of the CRH gene was confirmed by Southern blotting and restriction enzyme digestion. Combined in situ reverse transcription-PCR amplification/immunocytochemistry demonstrated the presence of CRH mRNA in corticotropes. Medium from anterior pituitary primary cultures contained $\sim 7 \mathrm{pg} / \mu \mathrm{g}$ protein of $\mathrm{CRH}$ immunoreactivity which presented the same chromatographic profile on HPLC as the mature CRH peptide. Incubation of anterior pituitary cells with an antibody directed against CRH markedly reduced basal ACTH secretion compared with serum-treated control wells $(0.89 \pm 0.11$ vs. $1.74 \pm 0.14 \mathrm{ng} / 200,000$ cells in control wells after $1 \mathrm{~h}$, $P<0.05 ; 1.17 \pm 0.10$ vs. $2.16 \pm 0.39 \mathrm{ng} / 200,000$ cells after $2 \mathrm{~h}, P<0.05 ; 1.45 \pm 0.12$ vs. $3.12 \pm 0.61 \mathrm{ng} / 200,000$ cells after $3 \mathrm{~h}, \mathrm{P}<0.05)$. Further, the ACTH response to potassium and to forskolin was markedly blunted by the CRH antiserum as well as by the CRH antagonist, $\alpha$-helical CRH(9-41). In conclusion, this study demonstrates the presence of $\mathrm{CRH}$ mRNA in normal rat corticotropes and the secretion of the mature peptide by the anterior pituitary, pointing to the production of $\mathrm{CRH}$ at the site of its target cells. In addition, intrapituitary $\mathrm{CRH}$ contributes in a paracrine/autocrine fashion to ACTH secretion. (J. Clin. Invest. 1998. 101:24782484.) Key words: hypothalamic releasing factors • corticotropes $\cdot$ gene expression $\cdot$ tissue distribution
\end{abstract}

Address correspondence to F. Pecori Giraldi, M.D., Ospedale San Luca, IRCCS, Istituto Auxologico Italiano, via Spagnoletto 3, Milan, 20149 Italy. Phone: 02-582161; FAX: 02-58216777; E-mail: FPG@ auxologico.it

Received for publication 21 April 1997 and accepted in revised form 1 April 1998.

J. Clin. Invest.

(C) The American Society for Clinical Investigation, Inc. 0021-9738/98/06/2478/07 \$2.00

Volume 101, Number 11, June 1998, 2478-2484

http://www.jci.org

\section{Introduction}

It is well known that anterior pituitary function is regulated both by hypothalamic neuropeptides and peripheral hormones which reach the gland via portal vessels and the systemic circulation, respectively. In addition to these blood-borne regulators, substances produced within the gland itself have been credited with an increasing importance in the regulation of adenohypophyseal hormone synthesis and secretion (1-3). The anterior pituitary has in fact been found to contain a wide variety of bioactive peptides, such as growth factors, cytokines, brain-gut peptides, and vasogenic substances $(2,3)$. The function of some of these substances within the anterior pituitary has been well documented, as for example for the vasoactive intestinal peptide (4), while it awaits definition for others. Quite recently, several members of another group of peptides, the hypothalamic releasing factors, have been demonstrated in the anterior pituitary. Their presence within the gland itself could represent yet another facet of adenohypophyseal physiology.

So far, conclusive evidence has been put forward for the synthesis and secretion of thyrotropin-releasing hormone (5, $6)$, somatostatin $(7,8)$, growth hormone-releasing hormone $(8$, $9)$, gonadotropin-releasing hormone $(10,11)$, and vasopressin $(12,13)$ by normal anterior pituitary cells. As regards corticotropin-releasing hormone $(\mathrm{CRH}),{ }^{1} \mathrm{mRNA}$ for this hormone has been found in the whole pituitary gland (14) but whether this signal derives from the adenohypophysis or the posterior pituitary, which cells are responsible for CRH gene expression, and whether locally produced $\mathrm{CRH}$ in fact modulates corticotrope secretion have not been established. Therefore, we decided to look for evidence of synthesis of CRH by the anterior pituitary and, if this is the case, to investigate its biological relevance towards ACTH secretion.

\section{Methods}

RNA extraction and PCR amplification. Adult male Sprague-Dawley rats (200-220 g body wt) were killed, and pituitaries were collected and dissected carefully into anterior and posterior lobes. Total RNA was extracted from pituitary fragments and dispersed anterior pituitary cells after $4 \mathrm{~d}$ in culture (vide infra), hypothalami (positive control), and liver (negative control) using the guanidinium-isothiocyanate protocol (15) (Tri Reagent; Molecular Research Center, Cincinnati, OH). RNA was quantitated and $1 \mu \mathrm{g}$ was reverse transcribed using the GeneAmp RNA PCR kit (Perkin Elmer, Foster City, CA). Reverse-transcribed cDNA was amplified with primers located on exon 2 of the rat CRH gene (14) (upstream primer: bp 306322, downstream primer: bp 523-539). The amplification protocol was

1. Abbreviations used in this paper: $\mathrm{ACN}$, acetonitrile; $\mathrm{CRH}$, corticotropin-releasing hormone; CRH-IR, CRH immunoreactivity; GAPDH, glyceraldehyde-3-phosphate dehydrogenase; NRS, normal rabbit serum; TFA, trifluoracetic acid. 
as follows: $4 \mathrm{~min}$ at $95^{\circ} \mathrm{C}, 2 \mathrm{~min}$ at $56^{\circ} \mathrm{C}$, and $2 \mathrm{~min}$ at $72^{\circ} \mathrm{C}$ for 1 cycle; $40 \mathrm{~s}$ at $95^{\circ} \mathrm{C}, 30 \mathrm{~s}$ at $56^{\circ} \mathrm{C}$, and $1 \mathrm{~min}$ at $72^{\circ} \mathrm{C}$ for 35 cycles followed by a 15 -min extension at $72^{\circ} \mathrm{C}$. One-tenth of the obtained PCR product was electrophoresed on a $4 \%$ agarose gel and stained with ethidium bromide.

Integrity of mRNA was verified by reverse-transcribing and amplifying the same samples with primers for the glyceraldehyde3-phosphate dehydrogenase (GAPDH) gene which were specifically designed to span an intron of $114 \mathrm{bp}$ (16). The amplification protocol was as follows: $20 \mathrm{~s}$ at $94^{\circ} \mathrm{C}, 5 \mathrm{~s}$ at $59^{\circ} \mathrm{C}$, and $1 \mathrm{~min}$ and $10 \mathrm{~s}$ at $72^{\circ} \mathrm{C}$ with a progressive increment of $0.01 \mathrm{~s} /$ cycle for 9 cycles; $20 \mathrm{~s}$ at $94^{\circ} \mathrm{C}$, $10 \mathrm{~s}$ at $58^{\circ} \mathrm{C}$, and $1 \mathrm{~min}$ and $10 \mathrm{~s}$ at $72^{\circ} \mathrm{C}$ with an increment of $0.01 \mathrm{~s} / \mathrm{cy}-$ cle for 25 cycles followed by $10 \mathrm{~s}$ at $58^{\circ} \mathrm{C}$ and a 15 -min extension at $72^{\circ} \mathrm{C}$. Amplification of reverse-transcribed cDNA gives rise to a 240-bp band whereas a band arising from genomic DNA would be 354 bp in length. Genomic contamination was also excluded by carrying out both CRH and GAPDH PCR amplification in samples not subjected to reverse transcription.

Restriction enzyme digestion and Southern blotting. After amplification with $\mathrm{CRH}$ primers, PCR products were purified and concentrated using the JetPure PCR purification kit (Genomed, Bad Oeynhausen, Germany) and one-third of the purified DNA incubated for $2 \mathrm{~h}$ at $37^{\circ} \mathrm{C}$ with either PstI (Amersham International, Little Chalfont, UK) or HaeIII (New England Biolabs, Beverly, MA). Digests were then electrophoresed and stained.

Another aliquot of the purified DNA was electrophoresed on a $4 \%$ agarose gel and transferred to a Nytran membrane (Hybond; Amersham International). The membrane was prehybridized in $6 \times$ SSC, $0.5 \%$ SDS, $5 \times$ Denhardt's solution, $0.01 \mathrm{M}$ Na phosphate, $1 \mathrm{mM}$ EDTA, and $100 \mu \mathrm{g} / \mathrm{ml}$ salmon sperm DNA for $2 \mathrm{~h}$ at $50^{\circ} \mathrm{C}$. An oligoprobe complementary to bp 479-503 of the rat CRH gene (14) was 5' end-labeled using T4 polynucleotide kinase (New England Biolabs) and $\left[\gamma^{-}{ }^{32} \mathrm{P}\right]$ ATP (Amersham International). The labeled oligoprobe was then added to the same solution and hybridization was carried out for $4 \mathrm{~h}$ at $50^{\circ} \mathrm{C}$. The membrane was washed three times for $2 \mathrm{~min}$ at room temperature and twice at $50^{\circ} \mathrm{C}$ in $2 \times \mathrm{SSC}, 0.1 \% \mathrm{SDS}$, thereafter $2 \mathrm{~min}$ at room temperature and $2 \mathrm{~min}$ at $50^{\circ} \mathrm{C}$ in $0.5 \times \mathrm{SSC}, 0.2 \%$ SDS. The filter was exposed overnight to an x-ray film (X-Omat AR; Eastman Kodak, Rochester, NY).

Combined in situ reverse transcription-PCR amplification/immunocytochemistry. In situ reverse transcription-PCR was performed with a slight modification of published protocols $(17,18)$. Dispersed pituitary cells (vide infra) were thoroughly washed with PBS and plated onto silane-coated slides at a density of 200,000 cells/section. Cells were fixed in 10\% buffered formalin (Sigma Chemical Co., St. Louis, MO) and digested overnight with RQ1 DNase (8 U/section) (Promega, Madison, WI). We found that permeabilization of cell monolayers with proteinase $\mathrm{K}$ (even with concentrations as low as 0.5 $\mu \mathrm{g} / \mathrm{ml}$ ) increased nonspecific stain, thus this step was omitted. Reverse transcription was performed as described above, whereas PCR amplification was shortened to 20 cycles and carried out in the presence of $200 \mu \mathrm{M}$ each dATP, dCTP, and dGTP, $190 \mu \mathrm{M}$ dTTP, and $10 \mu \mathrm{M}$ digoxigenin dUTP (Boehringer Mannheim, Indianapolis, IN). Detection of the digoxigenin-tagged PCR product was performed according to the manufacturer's instructions (Boehringer Mannheim) with the addition of $0.24 \mathrm{mg} / \mathrm{ml}$ levamisole (Sigma Chemical Co.) to the chromagen solution. Negative controls were: omission of reverse transcriptase; omission of primers; and omission of Taq polymerase. Immunocytochemistry was performed on the same specimens using an antibody against ACTH raised in rabbits (code No. N1531; DAKO Corp., Carpinteria, CA) and a three-step biotin-streptavidinperoxidase detection system (LSAB 2 kit; DAKO Corp.). Normal rabbit serum (NRS) obtained from the same supplier was used to check for nonspecific staining.

Modulation of ACTH secretion from anterior pituitary primary cultures by CRH antiserum or antagonist. Anterior pituitaries were dispersed with $0.1 \%$ collagenase in HAM-F10, plated at a density of 200,000 cells/well, and incubated at $37^{\circ} \mathrm{C}$ in DME, $10 \% \mathrm{FCS}, 0.05 \mathrm{mg} /$ $\mathrm{ml}$ ascorbic acid (Sigma Chemical Co.), $100 \mathrm{U} / \mathrm{ml}$ penicillin, $100 \mathrm{U} / \mathrm{ml}$ streptomycin, $10 \mathrm{mg} / \mathrm{ml}$ gentamycin, and $0.25 \mathrm{~g} / \mathrm{ml}$ amphotericin $B$ for $4 \mathrm{~d}$. Except for ascorbic acid, all other reagents for cell culture were purchased from Hyclone Ltd. (Cramlington, UK). On the day of the experiment, wells were washed in serum-free medium containing $0.1 \%$ BSA for $1 \mathrm{~h}$, before incubation with test agents. In the first set of experiments, wells were incubated up to $3 \mathrm{~h}$ with $\mathrm{CRH}$ antiserum (IgG Corp., Nashville, TN) at a final dilution of 1:300, 1:600, and 1:1,200 and medium samples were collected hourly for ACTH measurement. Control wells were incubated in the presence of an equal dilution of NRS. In the second set of experiments, wells were stimulated either with $40 \mathrm{mM}$ potassium chloride for 20 min or with $10 \mu \mathrm{M}$ forskolin for $3 \mathrm{~h}$ in the presence or absence of $50 \mathrm{nM} \alpha$-helical CRH(9-41) or CRH antiserum (dilution 1:300 and 1:1,200). Both forskolin and the CRH antagonist were purchased from Sigma Chemical Co. Medium was collected at the end of the incubation for ACTH measurement. ACTH RIA was performed according to the manufacturer's instructions (IgG Corp.) using tracer obtained from Amersham International. Inter- and intraassay coefficient of variation were 6.9 and $6.4 \%$, respectively.

Characterization of CRH immunoreactivity (CRH-IR) by HPLC. For characterization of CRH-IR in medium, wells were incubated in serum-free medium containing $0.1 \%$ BSA for $3 \mathrm{~h}$. Medium from three wells was then pooled and acidified with $1 \mathrm{~N}$ trifluoracetic acid (TFA). Samples were applied to Sep-Pack C18 columns (Millipore Corp., Bedford, MA) previously activated with $80 \%$ acetonitrile (ACN) in $0.01 \mathrm{~N}$ TFA. Columns were washed with $0.01 \mathrm{~N}$ TFA and samples eluted with $80 \% \mathrm{ACN}$ in $0.01 \mathrm{~N}$ TFA. After lyophilization, samples were reconstituted in $0.01 \mathrm{~N}$ TFA and applied to a Nucleosil C18 reverse phase column $(5 \mu \mathrm{m} ; 250 \times 4.6 \mathrm{~mm})$ attached to an 410 LC system (Perkin Elmer) and eluted with the following linear gradient: $0-35 \%$ ACN in $0.01 \mathrm{~N}$ TFA for $5 \mathrm{~min}, 35-65 \%$ ACN for $35 \mathrm{~min}$, and $65-80 \% \mathrm{ACN}$ for $10 \mathrm{~min}$ at $1 \mathrm{ml} / \mathrm{min}$. 1-min fractions were collected, lyophilized, and reconstituted in CRH RIA buffer (phosphate-EDTA, pH 7.4, containing $0.02 \%$ sodium azide). An equal volume of serum-free medium not used for cell culture (= blank) was subjected to Sep-Pack and HPLC purification before loading the culture sample. After HPLC purification of anterior pituitary culture medium, rat/human CRH(1-41) was loaded onto the column to determine the elution profile of the standard peptide. Reagents and materials for HPLC were purchased from Sigma Chemical Co. For quantitative purposes, medium from single wells was lyophilized for direct measurement of CRH-IR and protein content of each well was estimated after extraction of attached cells (19) (Bio-Rad Laboratories, Hercules, CA). CRH RIA was carried out at $4^{\circ} \mathrm{C}$ with a 100 -fold dilution of the antibody in NRS and delayed addition of tracer. The bound fraction was precipitated by the addition of a second antibody and centrifugation $\left(5,000 \mathrm{~g}\right.$ for $20 \mathrm{~min}$ at $\left.4^{\circ} \mathrm{C}\right)$. Assay sensitivity was 2 $\mathrm{pg} /$ tube while half-maximal displacement occurred at $13 \mathrm{pg} / \mathrm{tube}$. Intraassay coefficient of variation was $7.8 \%$. Rat/human CRH standard and antibodies for RIA were obtained from IgG Corp. while ${ }^{125} \mathrm{I}$ $\mathrm{Tyr}^{0}$-human/rat CRH was purchased from DuPont-NEN (Regensdorf, Switzerland).

Statistical analysis. Each treatment was carried out in six wells and experiments repeated at least twice. Student's $t$ test for unpaired data was used for comparison of absolute concentrations between treatments. Stimulated secretion was expressed as percent of basal secretion with each agent and differences between treatments assessed using Wilcoxon's rank test. Data are given as mean \pm SEM.

\section{Results}

PCR amplification of mRNA obtained from the hypothalamus and both the anterior and posterior pituitary using primers specific to the rat CRH gene gave rise to a single 232-bp band (Fig. 1). The band was clearly visible also in samples obtained from adenohypophyseal dispersed cells (Fig. 1). Genomic con- 


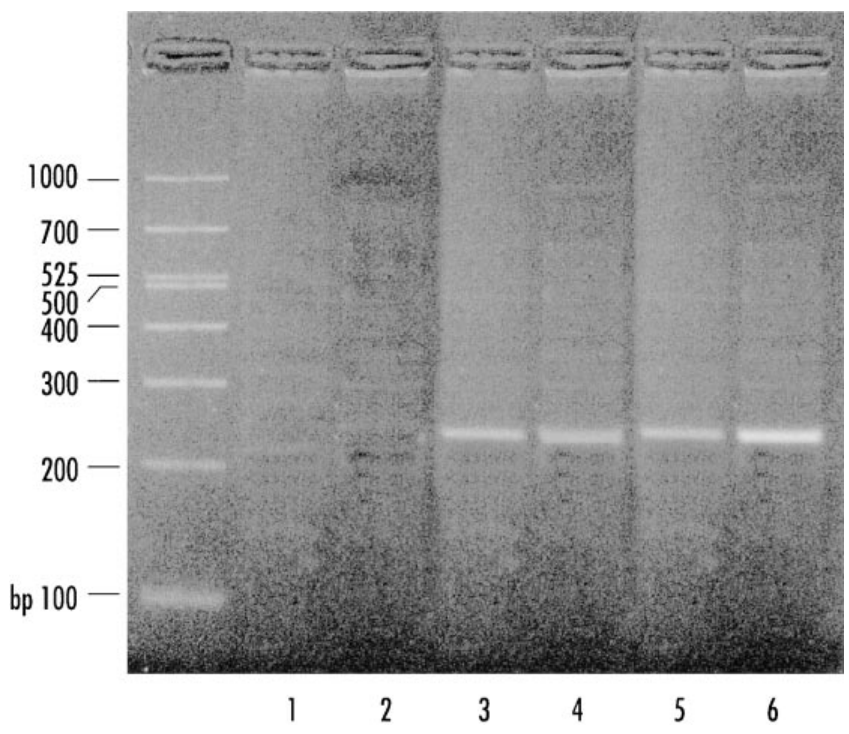

Figure 1. PCR amplification products of mRNA from the hypothalamus (lane 6), anterior pituitary tissue (lanes 5 and 1 ), primary culture (lane 4), neurohypophysis (lane 3), and liver (lane 2) using primers specific to CRH. In lane 1, PCR amplification of anterior pituitary mRNA samples was carried out without prior reverse transcription.

tamination of RNA samples can be excluded since amplification with GAPDH primers resulted only in the intron-less 240-bp fragment (data not shown). Further, no fragment was amplified from samples subjected to either GAPDH or CRH PCR amplification without prior reverse transcription (Fig. 1). These results clearly indicate that the obtained bands derive from mRNA. The identity of the fragments obtained by amplification with $\mathrm{CRH}$ primers was confirmed by restriction en-

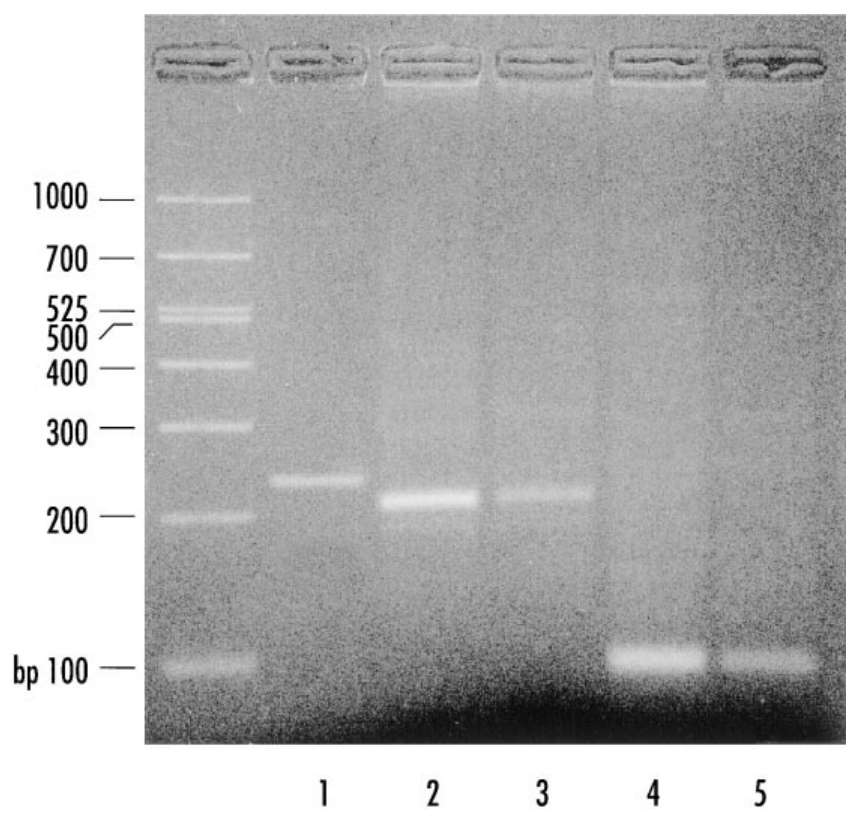

Figure 2. Restriction enzyme digestion of CRH PCR products. Lane 1, Hypothalamus; lane 2, PstI-digested hypothalamus; lane 3, PstIdigested anterior pituitary; lane 4, HaeIII-digested hypothalamus; lane 5, HaeIII-digested anterior pituitary.

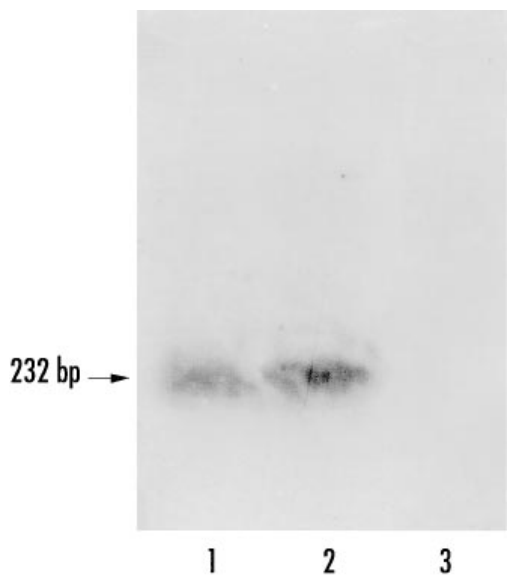

Figure 3. Southern blotting of CRH PCR products. Lane 1 , Hypothalamus; lane 2, anterior pituitary; lane 3 , liver. zyme digestion and Southern blotting. Digestion of the CRHPCR products with PstI (restriction sites at bp 320 and 330 of the CRH gene [14]) yielded a single 209-bp band whereas the smaller fragments (10 and 14 bp) ran off the gel (Fig. 2). Digestion with HaeIII (restriction sites at bp 401 and 496) gave rise to two 95-bp fragments and a smaller sized (43-bp) fragment not visible on gel (Fig. 2). On Southern blotting, a strong hybridization signal was evident at the site of the 232-bp band in both pituitary and hypothalamic samples (Fig. 3). PCR amplification of liver mRNA with primers for CRH as well as Southern blotting failed to yield a like-sized band (Figs. 1 and $3)$. The presence of mRNA in these samples was proven by amplification of the correct 240-bp band with GAPDH primers.

In situ reverse transcription-PCR amplification with primers specific for the CRH gene resulted in the incorporation of digoxigenin dUTP in single pituitary cells (Fig. 4, left). The specificity of the signal was ensured by failure to detect digoxigenin-labeled cells in negative controls (a representative section is shown in Fig. 4, right). Immunocytochemistry on the same sections revealed colocalization of CRH mRNA expression and ACTH immunoreactivity (Fig. 4, left), thus indicating that $\mathrm{CRH}$ gene expression occurs in corticotropes. No red stain could be detected in sections incubated with NRS instead of the ACTH antibody (data not shown).

HPLC purification of anterior pituitary culture medium revealed a clear peak of CRH-IR, coeluting with synthetic CRH(1-41) (Fig. 5). The presence of a smaller peak at lower mobility could indicate the presence of differently processed $\mathrm{CRH}$ peptides or the $\mathrm{CRH}$ precursor. Test medium alone (blank) did not contain CRH-IR. The prolonged period of attachment and the repeated washes before collection of the medium analyzed by HPLC nearly exclude contamination with $\mathrm{CRH}$ internalized by corticotropes or contained in monocytes or tissue macrophages. Measurement of CRH-IR in medium from primary cultures after $3 \mathrm{~h}$ of incubation yielded a concentration of $177.5 \pm 24.81 \mathrm{pg} / 200,000$ cells (corresponding to $1.2 \pm 0.39 \mathrm{fmol} / \mu \mathrm{g}$ protein). By comparison, the same wells secreted $\sim 1.6 \mathrm{ng} \mathrm{ACTH} \approx 14 \mathrm{fmol} / \mu \mathrm{g}$ protein $)$. CRH-IR increased significantly after a 20 -min stimulation with potassium $(229.5 \pm 9.69 \mathrm{pg} / 200,000$ cells vs. $141.9 \pm 21.86 \mathrm{pg} / 200,000$ cells in control wells, $P<0.05$ ).

Incubation of anterior pituitary cells with an antibody di- 

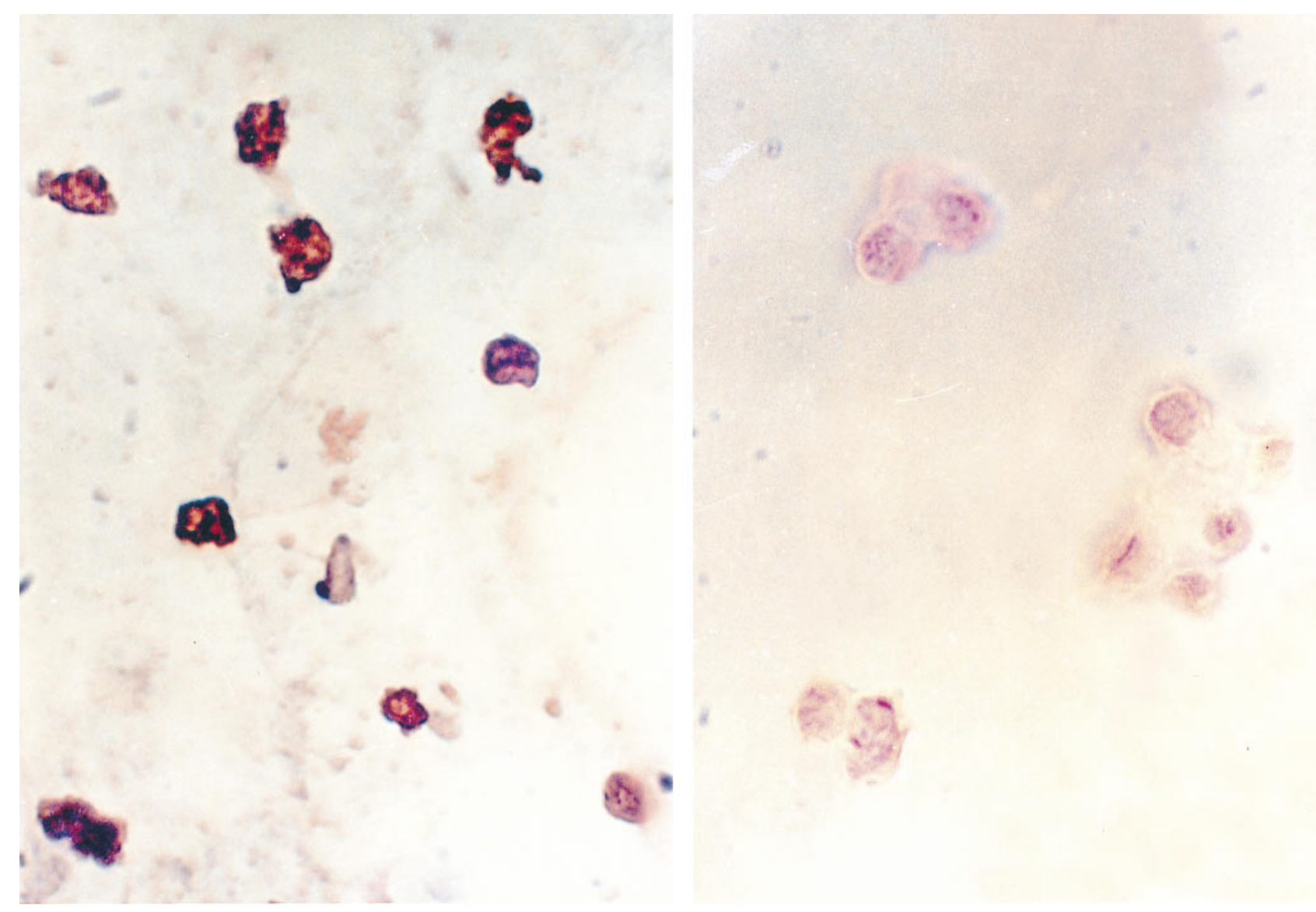

Figure 4. In situ reverse transcription-PCR amplification on dispersed anterior pituitary cells. (Left) PCR was carried out with primers specific for the $\mathrm{CRH}$ gene. Incorporation of digoxigenin dUTP gives rise to a blue-black signal by reaction with NBT/BCIP. Immunoreactivity for ACTH is visualized as a red stain with DAB $(\times 630)$. (Right) Reverse transcription-PCR carried out without reverse transcriptase (negative control) followed by immunocytochemistry $(\times 630)$.

rected against CRH markedly reduced ACTH concentrations in resting conditions compared with NRS-treated wells. This effect was observed at all dilutions used and a representative experiment is shown in Fig. 6. In agreement with previous studies (20), ACTH basal secretion was largely unaffected by $\alpha$-helical CRH(9-41) (data not shown). Stimulation with $40 \mathrm{mM}$ potassium and $10 \mu \mathrm{M}$ forskolin induced a clear-cut increase in ACTH, approximately twofold with potassium and fivefold with forskolin. These increases were noticeably blunted by the $\mathrm{CRH}$ antagonist (Fig. 7). The CRH antiserum clearly reduced ACTH secretion after cell depolarization but did not appear to affect its percent response to forskolin (Fig. 7). At closer scrutiny, however, the lack of an appreciable difference in percent stimulated values is probably due to the low ACTH levels observed with $\mathrm{CRH}$ antiserum alone by the third hour of incubation $(1.45 \pm 0.12$ vs. $3.12 \pm 0.61 \mathrm{ng} / 200,000$ cells in NRS-treated wells, $P<0.05$, Fig. 6 ). In fact, absolute ACTH concentrations after forskolin stimulation were substantially lower in antiserum-treated wells compared with NRS-treated wells $(6.7 \pm 0.27$ vs. $14.1 \pm 1.10 \mathrm{ng} / 200,000$ cells, $P<0.05)$. On the whole, these data can be taken to indicate an inhibitory effect of the $\mathrm{CRH}$ antiserum on both potassium- and forskolin-stimulated ACTH secretion.

\section{Discussion}

Paracrine and autocrine interactions within the anterior pituitary have engendered an increasing interest, as attested by several recent reviews $(1,3,21)$. The anterior pituitary has been found to harbor, apart from classical adenohypophyseal hormones, several other peptides which participate in cell-tocell interactions and modulate hormonal secretion (2). In this context, the synthesis of hypothalamic releasing factors, such as thyrotropin-releasing hormone, growth hormone-releasing hormone, somatostatin, and gonadotropin-releasing hormone has been demonstrated recently in normal and tumoral anterior pituitaries $(5,7,9,10,12)$. These factors exert direct effects on anterior pituitary hormone production and release as well as on cell differentiation and growth, via their receptors located on the pituicytes. Therefore, it is likely that small amounts of locally produced hypothalamic hypophysiotropic hormones can exert the actions of blood-borne neuropeptides. However, these peptides are internalized by their target cells and intrahypophyseal immunoreactivity could simply be due to receptor-mediated endocytosis. It follows, therefore, that demonstration of gene expression within the pituitary is crucial to state that local synthesis of these neuropeptides occurs. 


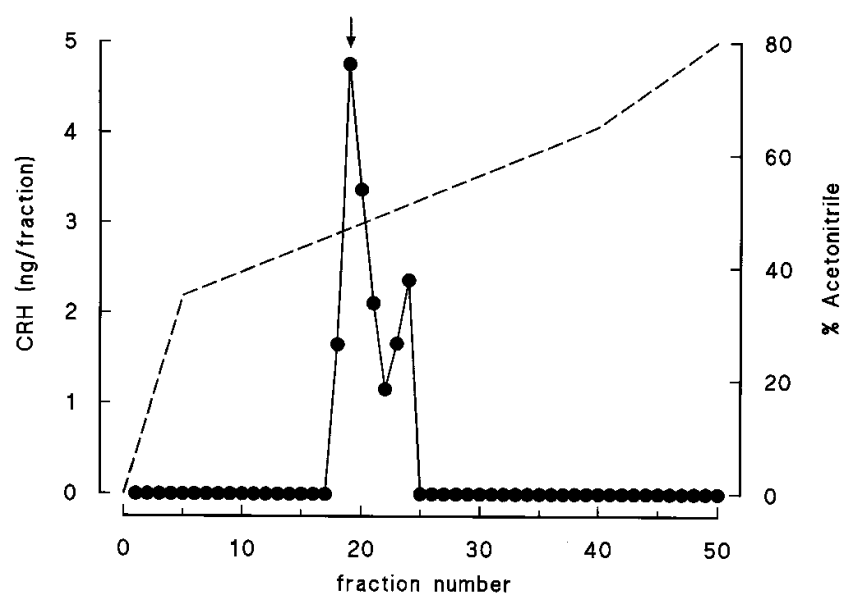

Figure 5. HPLC purification of anterior pituitary culture medium. Filled circles stand for CRH concentrations while the dashed line represents the $\mathrm{ACN}$ gradient. Arrow indicates elution fraction of rat/ human $\mathrm{CRH}(1-41)$.

Upon the cloning of the $\mathrm{CRH}$ gene, several tissues had been screened for its expression and CRH mRNA had been detected in the pituitary (14). However, the whole gland had been used in this study and no conclusions as to which pituitary lobe expressed the CRH gene could be drawn and, as a consequence, the possible functional importance of intrapituitary CRH remained elusive.

We decided to search for CRH gene expression in the anterior pituitary lobe using reverse transcription-PCR amplification. This technique is capable of detecting minute amounts of mRNA but, by virtue of its extreme sensitivity, is also susceptible to artifacts due to contamination with DNA or mRNA de-

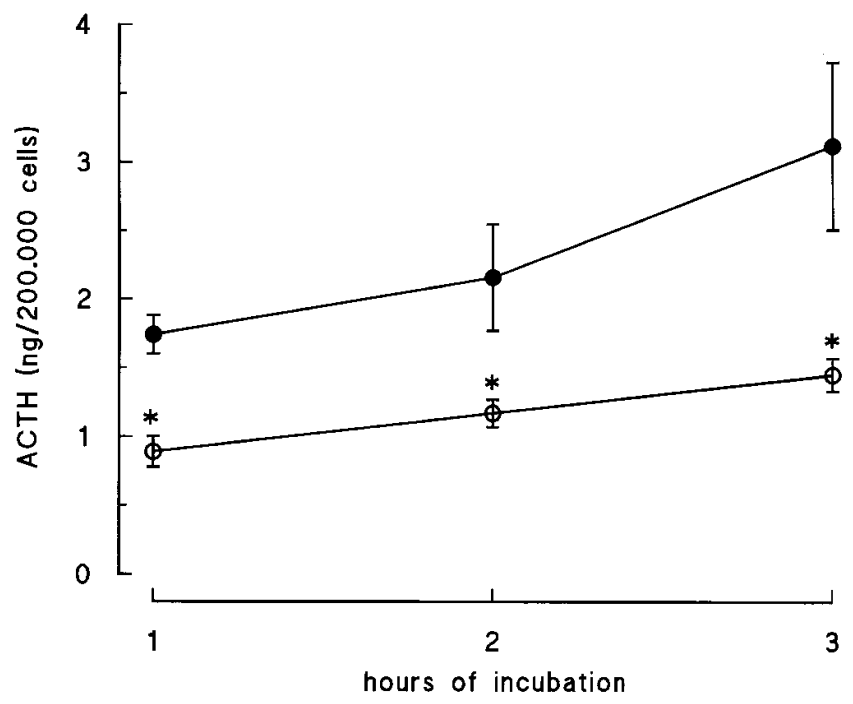

Figure 6. Effect of $\mathrm{CRH}$ antiserum on basal ACTH secretion from anterior pituitary cells in vitro. Wells were incubated with the CRH antibody at final dilution of 1:300 (open circles). Control wells were incubated with an equal dilution of NRS (filled circles). *Statistical significance of $P<0.05$ between antiserum and control wells at the same time point.
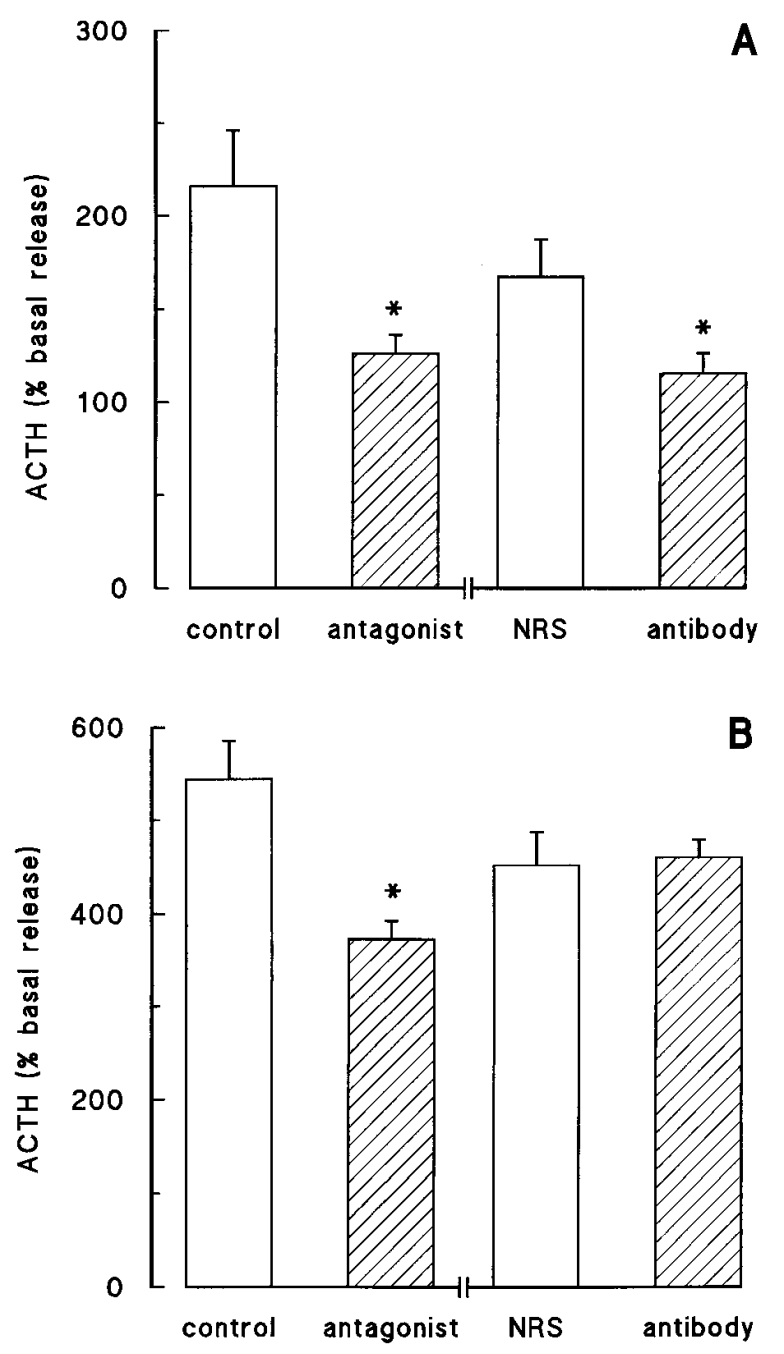

Figure 7. Effect of the $\mathrm{CRH}$ antagonist $\alpha$-helical $\mathrm{CRH}(9-41)$ and $\mathrm{CRH}$ antiserum on stimulated ACTH secretion from anterior pituitary cells in vitro. Results are expressed as percent of basal secretion with the same treatment ( $n=6$ for each treatment). Empty bars indicate control or NRS, whereas shaded bars correspond to secretion in presence of $50 \mathrm{nM} \alpha$-helical CRH(9-41) or 1:300 antiserum. ( $A$ ) Incubation for $20 \mathrm{~min}$ with $40 \mathrm{mM}$ potassium. (B) Incubation for $3 \mathrm{~h}$ with $10 \mu \mathrm{M}$ forskolin. *Statistical significance of $P<0.05$ between agents and respective controls.

rived from aspecific sources. Therefore, these issues were also addressed.

PCR amplification of pituitary mRNA with primers specific to the rat $\mathrm{CRH}$ gene yielded a DNA fragment of the same size as the one obtained from hypothalamic samples. Restriction enzyme digestion and Southern blotting using a nested probe confirmed that the band contained the expected sequence of the CRH gene. The likelihood of an artifact due to genomic contamination was excluded by the results of GAPDH PCR amplification and the absence of PCR products when the amplification was carried out without prior reverse transcription.

We also addressed the issue of which cells express the CRH gene in the anterior pituitary. To this purpose, we carried out in situ reverse transcription-PCR amplification followed by 
immunocytochemistry on dispersed pituitary cells. Using this approach we observed the presence of CRH mRNA in ACTH-immunoreactive cells, thus demonstrating that the $\mathrm{CRH}$ gene is expressed in corticotropes. Past cytochemical studies had in fact detected CRH-IR in rat corticotropes and not in other anterior pituitary cells but it had been postulated to reflect receptor-mediated internalization (22). However, in light of our findings, it seems likely that CRH-IR in corticotropes is due to the synthesis of the peptide within these cells. On the other hand, the specimens we used for this evaluation are dispersed pituitary cells with the obvious loss of intercellular tissue and interstitial cells. Previous studies had observed the presence of CRH mRNA in peripheral mononuclear cells and tissue macrophages (23) and these cells could theoretically contribute to the CRH PCR product in anterior pituitary tissue samples. However, no DNA fragment could be detected after amplification of liver mRNA with $\mathrm{CRH}$ primers, even on Southern blotting. As we and others (24) failed to detect CRH gene expression in the liver, a tissue quite rich in macrophages, it seems unlikely that the band obtained in pituitary samples arises from CRH mRNA contained in immune cells. On balance, our findings point to the corticotropes as the most likely site of $\mathrm{CRH}$ gene expression within the anterior pituitary. We also demonstrated the amplification of a CRH transcript from posterior pituitary mRNA. Therefore, it follows that the signal detected in whole pituitary samples on Northern blotting (14) derived from both pituitary lobes.

The next step in our study was to evaluate whether anterior pituitary cells can secrete the CRH peptide. To this purpose, medium from anterior pituitary primary cultures was purified by HPLC and the elution profile was determined. The major peak of CRH-IR in culture medium coeluted with CRH(1-41), the mature $\mathrm{CRH}$ peptide, indicating that anterior pituitary cells can correctly process the precursor. Concentrations of CRH-IR in culture medium were in the femtomolar range and increased after stimulation with a depolarizing agent. By contrast, ACTH levels were $\sim 10$-fold higher. The low concentrations of $\mathrm{CRH}$ support the concept of a locally acting peptide, whereas the ACTH-secreting machinery is geared at higher levels towards secretion into the blood stream.

Acting upon this results, we studied the effects of immunoneutralization and competitive antagonism of $\mathrm{CRH}$ on ACTH secretion from anterior pituitary cells in vitro. Incubation with $\mathrm{CRH}$ antiserum induced a marked decrease in basal and stimulated ACTH release. Basal ACTH secretion was unaffected by the CRH antagonist $\alpha$-helical $\mathrm{CRH}(9-41)$, in agreement with the first published study on this compound (20) whereas the ACTH response to both potassium and forskolin stimulation was blunted by the $\mathrm{CRH}$ antagonist. A previous study had failed to detect an inhibitory effect of $\alpha$-helical CRH(9-41) on forskolin-stimulated ACTH secretion (25). This discrepancy is most likely due to the different cell density and concentrations of antagonist used. As $\alpha$-helical CRH(941) competes with $\mathrm{CRH}$ for binding to its receptors (20) and the binding affinity of the pituitary $\mathrm{CRH}$ receptor is different for various ligands (26), the ratio of $\mathrm{CRH}$ antagonist to $\mathrm{CRH}$ peptide appears to be crucial for the inhibitory action. As a whole, our findings clearly indicate that $\mathrm{CRH}$ released by pituitary cells contributes to corticotrope secretion in resting and activated conditions.

The notion of a paracrine action of CRH has been demonstrated in several tissues, first and foremost the placenta where
CRH influences blood flow, prostaglandin synthesis and, ultimately, labor (27). CRH is also synthesized in other tissues of the reproductive system, such as the ovaries (28), the endometrium $(29,30)$, and the testis (31) and has been found to modulate local cellular activities $(32,33)$. Also the adrenal gland contains CRH (34) where it appears to act as a secretagogue for corticosterone secretion (35) and medullary ACTH secretion (36). Other important sites of CRH production, as mentioned before, are lymphocytes and macrophages (23) and the paracrine action of $\mathrm{CRH}$ on immune function has been established clearly (37).

Various lines of evidence suggest that ACTH secretion can be modulated, apart from blood-borne hormones, also by cellto-cell interactions $(38,39)$. First, several substances produced by the anterior pituitary are known to influence corticotrope secretion. Acetylcholine $(40,41)$ and chromogranin A (42), for example, inhibit ACTH release whereas epidermal growth factor plays a role in the recruitment of corticotropes $(43,44)$. Concurrently, experiments using a cytotoxic conjugate which selectively destroys CRH target cells $(45,46)$ or in which the distance between plated cells was manipulated (39) have provided compelling evidence for paracrine communication among distinct subtypes of corticotropes. Further, some investigators have postulated that the well known potentiation of CRH responsiveness induced by vasopressin $(47,48)$ might be mediated by paracrine interactions (46). On balance, paracrine/autocrine communications play a significant role in modulating corticotrope activity and we now have identified CRH as another possible player in this intrapituitary circuit. Hypothetically, a given stimulus could act within the pituitary to induce both ACTH and CRH release, thus amplifying the signal driving corticotrope secretion.

In conclusion, our study provides definitive evidence that the anterior pituitary synthesizes and secretes biologically active CRH. The cells responsible for CRH gene expression in the pituitary appear to be the corticotropes. Further, we demonstrated that locally produced $\mathrm{CRH}$ effectively contributes to ACTH secretion. Given this novel evidence, anterior pituitary $\mathrm{CRH}$ could be involved in several aspects of both corticotrope physiology and pathophysiology, such as Cushing's disease or isolated ACTH deficiency. Future studies will hopefully shed light on the importance of this additional location of $\mathrm{CRH}$ within the hypothalamic-pituitary-adrenal axis.

\section{References}

1. Schwartz, J., and R. Cherny. 1992. Intercellular communication within the anterior pituitary influencing the secretion of hypophyseal hormones. Endocrine Rev. 13:453-475.

2. Houben, H., and C. Denef. 1994. Bioactive peptides in anterior pituitary cells. Peptides. 15:547-582.

3. Renner, U., U. Pagotto, E. Arzt, and G.K. Stalla. 1996. Autocrine and paracrine roles of polypeptide growth factors, cytokines and vasogenic substances in normal and tumorous pituitary function and growth: a review. Eur. J. Endocrinol. 135:515-532.

4. Nagy, G.M., J.J. Mulchahey, and J.D. Neill. 1988. Autocrine control of prolactin secretion by vasoactive intestinal peptide. Endocrinology. 122:364-366.

5. Pagesy, P., G. Croissandeau, M. Le Dafniet, F. Peillon, and J.Y. Li. 1992. Detection of thyrotropin-releasing hormone (TRH) mRNA by the reverse transcription-polymerase chain reaction in the human normal and tumoral anterior pituitary. Biochem. Biophys. Res. Commun. 182:182-187.

6. Bruhn, T.O., T.G. Bolduc, D.B. MacLean, and I.M.D. Jackson. 1991. ProTRH peptides are synthesized and secreted by anterior pituitary cells in long-term culture. Endocrinology. 129:556-558.

7. Pagesy, P., J.Y. Li, F. Rentier-Delrue, Y. Le Bouc, J.A. Martial, and F. Peillon. 1989. Evidence of pre-prosomatostatin mRNA in human normal and tumoral anterior pituitary gland. Mol. Endocrinol. 3:1289-1294. 
8. Joubert, D., C. Benlot, A. Lagoguey, P. Garnier, A.M. Brandi, J.P. Gautron, J.C. Legrand, and F. Peillon. 1989. Normal and growth hormone $(\mathrm{GH})$-secreting adenomatous human pituitaries release somatostatin and $\mathrm{GH}-$ releasing hormone. J. Clin. Endocrinol. Metab. 68:572-577.

9. Moretti, C., M.L. Scaldaferri, A. Bagnato, and G. Frajese. 1995. Local synthesis of growth hormone releasing hormone $(\mathrm{GHRH})$ in rat pituitary gland. XXVI National Congress of the Italian Society of Endocrinology, Pisa. 18 (Suppl. 5):138. (Abstr.)

10. Pagesy, P., J.Y. Li, M. Berthet, and F. Peillon. 1992. Evidence of gonadotropin-releasing hormone mRNA in the rat anterior pituitary. Mol. Endocrinol. 6:523-528.

11. May, V., J.F. Wilber, D.C. U'Prichard, and G.V. Childs. 1987. Persistence of immunoreactive TRH and GnRH in long-term primary anterior pituitary cultures. Peptides. 8:543-558.

12. Loh, Y.P., M.G. Castro, F.J. Zeng, and U. Patel-Vaidya. 1988. Presence of provasopressin mRNA, neurophysin, and arginine vasopressin in mouse anterior pituitary cells and the AtT-20 corticotrophic tumour cell line. J. Mol. Endocrinol. 1:39-48.

13. Terrier, C., J.G. Chabot, G. Pautrat, L. Jeandel, D. Gray, B. LutzBucher, H.H. Zingg, and G. Morel. 1991. Arginine-vasopressin in anterior pituitary cells: in situ hybridization of mRNA and ultrastructural localization of immunoreactivity. Neuroendocrinology. 54:303-311.

14. Thompson, R.C., A.F. Seasholtz, and E. Herbert. 1987. Rat corticotropin-releasing hormone gene: sequence and tissue-specific expression. Mol. Endocrinol. 1:363-370.

15. Chomczynski, P., and N. Sacchi. 1987. Single-step method of RNA isolation by acid guanidinium thiocyanate-phenol-chloroform extraction. Anal. Biochem. 162:156-159.

16. Ryan, I.P., E.D. Schriock, and R.N. Taylor. 1994. Isolation, characterization and comparison of human endometrial and endometriosis cells in vitro. J. Clin. Endocrinol. Metab. 78:642-648.

17. Heniford, B.W., A. Shum-Siu, M. Leonberger, and F.J. Hendler. 1993. Variation in cellular EGF receptor mRNA expression demonstrated by in situ reverse transcriptase polymerase chain reaction. Nucleic Acids Res. 21:31593166 .

18. Martinez, A., M.J. Miller, K. Quinn, E.J. Unsworth, M. Ebina, and F. Cuttitta. 1995. Non-radioactive localization of nucleic acids by direct in situ PCR and in situ RT-PCR in paraffin-embedded sections. J. Histochem. Cytochem. 43:739-747.

19. Bradford, M.M. 1976. A rapid and sensitive method for the quantitation of microgram quantities of protein using the principle of protein-dye binding. Anal. Biochem. 72:248-254.

20. Rivier, J., C. Rivier, and W.W. Vale. 1984. Synthetic competitive antagonists of corticotropin-releasing factor: effect on ACTH secretion in the rat. Science. 224:889-891.

21. Schwartz, J., and F.M. Perez. 1994. Intercellular interactions in the anterior pituitary. J. Endocrinol. Invest. 17:459-470.

22. Childs, G.V., J.L. Morell, A. Niendorf, and G. Aguilera. 1986. Cytochemical studies of corticotropin-releasing factor (CRF) receptors in anterior lobe corticotropes: binding, glucocorticoid regulation, and endocytosis of [biotinyl-Ser ${ }^{1}$ CRF. Endocrinology. 119:2129-2142.

23. Stephanou, A., D.S. Jessop, R.A. Knight, and S.L. Lightman. 1990. Corticotropin-releasing factor-like immunoreactivity and mRNA in human leukocytes. Brain Behav. Immun. 4:67-73.

24. Aird, F., C.V. Clevenger, M.B. Prystowsky, and E. Redei. 1993. Corticotropin-releasing factor messenger RNA in rat thymus and spleen. Proc. Natl. Acad. Sci. USA. 90:7104-7108.

25. Rosenthal, M.J., J.C. Kraner, and G.T. Peake. 1987. Site of inhibitory action of CRH 9-41 on ACTH release from isolated rat pituitary cells. Life Sci. 40:1179-1184.

26. Chen, R., K.A. Lewis, M.H. Perrin, and W.W. Vale. 1993. Expression cloning of a human corticotropin-releasing factor receptor. Proc. Natl. Acad. Sci. USA. 90:8967-8971.

27. Challis, J.R.G., S.G. Matthews, C. van Meir, and M.M. Ramirez. 1995. Current topic: the placental corticotrophin-releasing hormone-adrenocorticotrophin axis. Placenta. 16:481-502.

28. Mastorakos, G., E.L. Webster, T.C. Friedman, and G.P. Chrousos. 1993. Immunoreactive corticotropin-releasing hormone and its binding sites in the rat ovary. J. Clin. Invest. 92:961-968

29. Petraglia, F., S. Tabanelli, M.C. Galassi, G.C. Garuti, A.C. Mancini, A.R. Genazzani, and E. Gurpide. 1992. Human decidua and in vitro decidualized endometrial stromal cells at term contain immunoreactive corticotropinreleasing factor (CRF) and CRF messenger ribonucleic acid. J. Clin. Endocrinol. Metab. 74:1427-1431.

30. Di Blasio, A.M., F. Pecori Giraldi, P. Viganò, F. Petraglia, M. Vignali, and F. Cavagnini. 1997. Expression of corticotrophin-releasing hormone and its R1 receptor in human endometrial stromal cells. J. Clin. Endocrinol. Metab. 82: 1594-1597.

31. Fabbri, A., J.C. Tinajero, and M.L. Dufau. 1990. Corticotropin-releasing factor is produced by rat Leydig cells and has a major local antireproductive role the testis. Endocrinology. 127:1541-1543.

32. Gerendai, I., A. Nemeskéri, and V. Csernus. 1992. Effect of intratesticular administration of anti-corticotropin-releasing factor antiserum (a-CRF) on testicular function in neonatal rats. Andrologia. 25:211-215.

33. Ferrari, A., F. Petraglia, and E. Gurpide. 1995. Corticotropin-releasing factor decidualizes human endometrial stromal cells in vitro. Interaction with progestin. J. Steroid Biochem. Mol. Biol. 54:5-6.

34. Suda, T., N. Tomori, F. Tozawa, H. Demura, K. Shizume, T. Mouri, Y. Miura, and N. Sasano. 1984. Immunoreactive corticotropin and corticotropinreleasing factor in human hypothalamus, adrenal, lung cancer, and pheochromocytoma. J. Clin. Endocrinol. Metab. 58:919-924.

35. Andreis, P.G., G. Neri, G. Mazzocchi, F. Musajo, and G.G. Nussdorfer. 1992. Direct secretagogue effect of corticotropin-releasing factor on the rat adrenal cortex: the involvement of the zona medullaris. Endocrinology. 131:69-72.

36. Mazzocchi, G., L.K. Malendowicz, A. Markowska, and G.G. Nussdorfer. 1994. Effect of hypophysectomy on corticotropin-releasing hormone and adrenocorticotropin immunoreactivities in the rat adrenal gland. Mol. Cell. Neurosci. 5:345-349.

37. Karalis, K., H. Sano, J. Redwine, S. Listwak, R.L. Wilder, and G.P. Chrousos. 1991. Autocrine or paracrine inflammatory actions of corticotropinreleasing hormone in vivo. Science. 254:421-423.

38. Schwartz, J., B. Canny, W.W. Vale, and J.W. Funder. 1989. Intrapituitary cell-cell communication regulates ACTH secretion. Neuroendocrinology. 50:716-722.

39. Jia, L.G., B. Canny, and D.A. Leong. 1992. Paracrine communication regulates adrenocorticotropin secretion. Endocrinology. 130:534-539.

40. Carmeliet, P., and C. Denef. 1989. Synthesis and release of acetylcholine by normal and tumoral pituitary corticotropes. Endocrinology. 124:2218-2227.

41. Heisler, S., L. Larose, and J. Morriset. 1983. Muscarinic cholinergic inhibition of cyclic AMP formation and ACTH secretion in mouse pituitary tumor cells. Biochem. Biophys. Res. Commun. 114:289-295.

42. Wand, G.S., M. Takayyuddin, D.T. O'Connor, and M.A. Levine. 1990. A proposed role of chromogranin A as a glucocorticoid-response autocrine inhibitor of proopiomelanocortin secretion. Endocrinology. 128:1345-1351.

43. Childs, G.V., D. Rougeau, and G. Unabia. 1995. Corticotropin-releasing hormone and epidermal growth factor: mitogens for anterior pituitary corticotropes. Endocrinology. 136:1595-1602.

44. Childs, G.V., J. Patterson, G. Unabia, D. Rougeau, and P. Wu. 1991. Epidermal growth factor enhances ACTH secretion and expression of POMC mRNA by corticotropes in mixed and enriched cultures. Mol. Cell. Neurosci. 2: 235-243.

45. Schwartz, J., B. Penke, J. Rivier, and W.W. Vale. 1987. A new cytotoxin specific for the target cells of corticotropin-releasing factor. Endocrinology. 121:1454-1460.

46. Schwartz, J., and W.W. Vale. 1988. Dissociation of the adrenocorticotropin secretory responses to corticotropin-releasing factor (CRF) and vasopressin or oxytocin by using a specific cytotoxic analog of CRF. Endocrinology. 122:1695-1700.

47. Giguere, V., and F. Labrie. 1982. Vasopressin potentiates cyclic AMP accumulation and ACTH release induced by corticotropin-releasing factor $(\mathrm{CRF})$ in rat anterior pituitary cells in culture. Endocrinology. 111:1752-1754.

48. de Bold, C.R., W.R. Sheldon, G.S. DeCherney, R.V. Jackson, A.N. Alexander, W.W. Vale, J. Rivier, and D.N. Orth. 1984. Arginine vasopressin potentiates adrenocorticotropin release induced by ovine corticotropin-releasing factor. J. Clin. Invest. 73:533-538. 